Ante Paić, mag. iur. ${ }^{1}$

\title{
PRAVNI POLOŽAJ IZLUČNIH VJEROVNIKA U PREDSTEČAJNOM I STEČAJNOM POSTUPKU
}

\author{
Pregledni rad / Review paper \\ UDK/UDC: 347.736 \\ DOI: $10.51650 /$ ezrvs.15.3-4.9 \\ Primljeno / Received: 29/7/2021 \\ Prihvaćeno / Accepted: 4/10/2021
}

\begin{abstract}
U ovom radu se daje prikaz izlučnih prava i pravnog položaja izlučnih vjerovnika u predstečajnom i stečajnom postupku. U radu je posebna pozornost posvećena razmatranju predmeta izlučnog prava i pravnoj osnovi za izlučenje predmeta iz stečajne mase, a također se raspravlja io tome što je bitno za ostvarenje izlučnog prava, o naknadi za izlučna prava io pravnom položaju izlučnih vjerovnika u slučaju prodaje imovine dužnika kao cjeline.
\end{abstract}

Ključne riječi: izlučno pravo, izlučni vjerovnici, predmet izlučenja, osnov izlučenja.

\section{Uvodne napomene}

Prema Stečajnom zakonu (u daljnjem tekstu: SZ)² predstečajni postupak se provodi radi uređivanja pravnog položaja dužnika i njegova odnosa prema vjerovnicima i održavanja njegove djelatnost, dok je osnovni cilj i svrha zbog kojeg se provodi stečajni postupak skupno namirenja vjerovnika stečajnog dužnika, unovčenjem njegove imovine i podjela prikupljenih sredstava vjerovnicima. Međutim ako postoji gospodarski održivo poslovanje dužnika onda se nakon otvaranja stečajnog postupka, odnosno tijekom stečajnog postupka može provesti stečajni plan u kojem se može odstupiti od zakonskih odredaba o unovčenju i raspodjeli stečajne mase. Kako se stečajni postupak može provesti i nad pravnom osobom i nad imovinom dužnika pojedinca propisano je da će se poštenim dužnicima pojedincima omogućit oslobođenje od preostalih obveza prema odredbama glave IX. Stečajnog zakona (čl. 2. st. 1.-3. SZ).

Bitno je za ovaj rad istaknuti da otvaranjem stečajnog postupka imovina stečajnog dužnika postaje stečajna masa koja služi za namirenje tražbina vjerovnika stečajnog dužnika. Sve osobe koje imaju određenu tražbinu prema stečajnom dužniku su vjerovnici tog stečajnog dužnika, ali prema svom položaju u okviru stečajnog postupka razlikuju se četiri kategorije vjerovnika stečajnog dužnika i to stečajni vjerovnici, izlučni vjerovnici, razlučni vjerovnici i vjerovnici stečajne mase.

\footnotetext{
1 Vodovod i odvodnja d.o.o., Šibenik; e-mail: ante.paic@vodovodsib.hr

2 Stečajni zakon, Narodne novine, br. 71/15, 104/17.
} 


\section{Pojam - izlučna prava u predstečajnom i stečajnom postupku}

Prema čl. 147. st. 1. SZ osoba koja na temelju kojeg svog stvarnog ili osobnog prava može dokazati da neki predmet ne ulazi u stečajnu masu nije stečajni vjerovnik. Njezino će se pravo na izdvajanje predmeta utvrđivati prema pravilima za ostvarivanje tih prava izvan stečaja. Drugim riječima, izlučno pravo u stečaju jest pravo koje ovlašćuje izlučnog vjerovnika da zahtijeva od stečajnog dužnika da iz stečajne mase izdvoji i da mu se preda određeni predmet za kojeg dokaže da ne spada u stečajnu masu i da na temelju nekog svog stvarnog ili osobnog prava ima pravo zahtijevati njegovo izdvajanje po pravilima koji važe za ostvarivanje tih prava izvan stečajnog postupka. Naime, određene stvari mogu biti u faktičnoj vlasti stečajnog dužnika, ali nisu dio stečajne mase jer druge osobe imaju stvarna prava na njima koja ih ovlašćuju da zahtijevaju izlučenje stvari iz stečajne mase. Prema tome, izlučni vjerovnici su osobe koje na temelju nekog stvarnog prava ili osobnog prava mogu zahtijevati da se neki predmet (stvar ili pravo) izluči iz stečajne mase zbog razloga što ne pripada stečajnom dužniku. ${ }^{3}$

Izlučni vjerovnici nisu stečajni vjerovnici, a što proizlazi iz izričito propisane odredbe čl. 147. st. 1. SZ da osoba koja na temelju kojega svog stvarnog ili osobnog prava može dokazati da neki predmet ne ulazi u stečajnu masu nije stečajni vjerovnik. Ako je pravo izlučnog vjerovnika upisano u javnoj knjizi, stečajni dužnik mora dokazati da predmet na koji se to pravo odnosi ulazi u stečajnu masu (čl. 147. st. 2. SZ).

Pravo izlučnih vjerovnika na izdvajanje predmeta utvrđuje se prema pravilima koja važe za ostvarivanje tih prava izvan predstečajnog, odnosno stečajnog postupka. Izlučno pravo najčešće se temelji na pravu vlasništva izlučnog vjerovnika na određenoj stvari ili pravu, ali se može temeljiti i na nekoj drugoj pravnoj osnovi (ugovor o zakupu, posudbi, djelu) ${ }^{4}$. Bitno je da određena stvar ili pravo nije imovina dužnika. ${ }^{5}$

Shodno gore navedenom, za postojanje izlučnog prava bitno je: 1.) da se u stečajnoj masi nalazi određeni predmet ili se nalazio, a dužnik ili stečajni upravitelj odnosno privremeni stečajni upravitelj ga je neovlašteno otuđio, 2.) da taj predmet ne ulazi u imovinu stečajnog dužnika, 3.) da izlučni vjerovnik ima valjanu pravnu osnovu na kojoj temelji zahtjev (stvarnopravni ili obveznopravni) za izlučenje i predaju u posjed i 4.) da to svoje pravo ostvaruje po općim pravilima neovisno o samom stečajnom postupku, na jednak način kao i da stečaja nema. ${ }^{6}$

lako Stečajni zakon izričito ne određuje posebnu definiciju izlučnih prava za predstečajni postupak, pojam izlučnih prava u predstečajnom postupku isti je kao i u stečajnom postupku.

\section{Pravni položaj izlučnih vjerovnika u predstečajnom postupku}

Rješenje o otvaranju predstečajnog postupka objavljuje se na internetskoj stranici e-oglasna ploča istog dana kad je doneseno rješenje o otvaranju postupka (čl. 33. st. 1.-3. SZ). To je bitno jer tada nastupaju pravne, procesnopravne i materijalnopravne posljedice. Pravne posljedice otvaranja predstečajnnog postupka nastaju za sve tražbine vjerovnika

\footnotetext{
${ }^{3}$ Dika, Mihajlo, Insolvencijsko pravo, Pravni fakultet u Zagrebu, Zagreb, 1998., str. 29.

4 Više o tome u odjeljku 4.4. ovoga rada, str. 117.-124.

${ }^{5}$ Marković, Nevenka, Pravni položaj vjerovnika u postupku predstečajne nagodbe, u knjizi: Barbić, Jakša (ur.), Hrvatsko insolvencijsko pravo, Hrvatska akademija znanosti i umjetnosti, Zagreb, 2014., str. 121.

${ }^{6}$ Eraković, Andrija, Izlučna i razlučna prava u stečaju, Zbornik Pravnog fakulteta u Rijeci, 2003, br. 1., str. 641.
} 
prema dužniku koje su nastale do otvaranja postupka, ako Stečajnim zakonom nije drukčije određeno (čl. 65. st. 3. SZ). Međutim, predstečajni postupak nažalost ne utječe na pravo odvojenog namirenja izlučnih vjerovnika. (čl. 66. st. 1. toč. 1. SZ). Prema Garašić, dvojbeno je ponajprije hoće li se moći osmisliti plan restrukturiranja koji će se doista realizirati, a da se u restrukturiranje ne uključe izlučni i razlučni vjerovnici, to stoga jer je imovina dužnika sa financijskim teškoćama u pravilu pokrivena izlučnim i razlučnim pravima. ${ }^{7}$

\subsection{Obavijest o izlučnom pravu u predstečajnom postupku}

U predstečajnom postupku izlučni vjerovnici ne prijavljuju svoje pravo već samo obavještavaju o postojanju izlučnog prava. Naime, izlučni su vjerovnici dužni nadležnu jedinicu Financijske agencije (dalje u tekstu: FINA) ${ }^{8}$ u roku za prijavu tražbine (u roku od 21 dan od dana dostave rješenja o otvaranju predstečajnog postupka) obavijestiti o svojim pravima, pravnoj osnovi izlučnog prava i dijelu imovine dužnika na koji se odnosi njihovo izlučno pravo (čl. 38. st. 2. SZ). Isto tako, razlučni i izlučni vjerovnici dužni su u obavijesti dati izjavu o pristanku ili uskrati pristanka odgode namirenja iz predmeta na koji se odnosi njihovo razlučno pravo, odnosno izdvajanje predmeta na koje se odnosi njihovo izlučno pravo radi provedbe plana restrukturiranja (čl. 38. st. 3. SZ). Ako je dao pristanak izlučni vjerovnik može opozvati tu svoju izjavu najkasnije do početka ročišta za glasovanje o planu restrukturiranja ako su planom restrukturiranja njihova prava smanjena ili je ostvarenje njihova prava izmijenjeno nakon dane izjave (čl. 38. st. 5. SZ).

Ovdje je bitno istaknuti da rješenje o otvaranju predstečajnog postupka ne sadrži poziv izlučnim vjerovnicima da obavijeste nadležnu jedinicu FINA o postojanju izlučnog prava (čl. 34. SZ). Mišljenja sam da bi bilo mnogo bolje i korisnije za vjerovnike kad bi rješenje o otvaranju predstečajnog postupka sadržavalo i poziv izlučnim vjerovnicima da u roku za prijavu tražbine moraju obavijestiti nadležnu jedinicu FINA o postojanju svog izlučnog prava iz razloga što bi stečajni vjerovnici tako mogli biti upoznati o tim pravima, odnosno imati saznanje koji dio imovine koju koristi dužnik nije njegovo vlasništvo, već vlasništvo izlučnih vjerovnika.

Izlučni vjerovnici gore navedenu obavijest i izjavu daju na Obrascu 3. koji nosi naziv Prijava tražbine vjerovnika u predstečajnom postupku. ${ }^{9}$ lako predmetni obrazac ima posebno istaknute rubrike o izlučnom i razlučnom pravu, mišljenja sam da propisana upotreba navedenog obrasca koja nosi naziv „prijava tražbina“ izaziva nejasnoće, a naročito ako se istovremeno ne prijavljuje i tražbina.

Nadalje, na ročištu radi ispitivanja tražbina ispituju se tražbine vjerovnika, dok se o izlučnim pravima ne raspravlja jer ta prava nisu predmetom ispitivanja (čl. 46. st. 6. SZ). Prema tome, sud u predstečajnom postupku nije nadležan odlučivati o zahtjevu izlučnih vjerovnika, već oni svoja prava i interese ako su povrijeđena i ugrožena mogu ostvarivati izvan predstečajnog postupka.

7 Garašić, Jasnica, Najznačajnije novine stečajnog zakona iz 2015. godine, Zbornik Pravnog fakulteta u Rijeci, 2017, br. 1., str. 143.

${ }^{8}$ Vidjeti Pravilnik o popisu jedinica Financijske agencije i područja njihove nadležnosti u predstečajnom postupku, Narodne novine 106/15.

9 Vidi, Pravilnik o sadržaju i obliku obrazaca na kojima se podnose podnesci u predstečajnom i stečajnom postupku, Narodne novine br. 71/15. 


\subsection{Utjecaj otvaranja predstečajnog postupka na pravo izlučnih vjerovnika}

Pravne posljedice otvaranja predstečajnog postupka nastaju za sve tražbine vjerovnika prema dužniku koje su nastale do otvaranja predstečajnog postupka, no izričito je u članku 66. st. 1. toč. 1. SZ predviđeno da predstečajni postupak ne utječe na prava koja imaju izlučni vjerovnici. Prema tome, za razliku od ostalih tražbina koje nisu izričito navedene u čl. 66 . SZ kao izuzete od utjecaja otvaranja predstečajnog postupka i koje svi ostali vjerovnici moraju prijaviti, otvaranje predstečajnog postupka „nažalost“ ne utječe na izlučne vjerovnike. Ovdje sam mišljenja da bi kod dužnika s financijskim poteškoćama kod kojeg bi imovina bila pokrivena izlučnim pravima bilo teško osmisliti plan restrukturiranja iz razloga što se dužnik koristi imovinom trećih u odnosu na koja postoje izlučna prava. Stoga, bez daljnjeg korištenja predmeta na kojima postoji izlučno pravo dužnik u pravilu neće biti u mogućnosti ostvariti plan restrukturiranja.

\section{Pravni položaj izlučnih vjerovnika u stečajnom postupku}

Budući da je bitan trenutak u kojem su treće osobe mogle saznati za otvaranje stečajnog postupka, to je od iznimne važnosti da se utvrdi kada je došlo do otvaranja stečajnog postupka. Taj trenutak je bitan jer za sobom povlači brojne pravne posljedice kao što su npr. prijelaz prava dužnikovih tijela na stečajnog upravitelja, također se gase računi dužnika i prestaju prava osoba koje su bile ovlaštene raspolagati imovinom dužnika na tim računima, stečajni upravitelj će otvoriti nove račun(e) dužnika, uz tvrtku ili naziv dužnika dodaje se dodatak „u stečaju“, zatim obveza prijavljivanja tražbina vjerovnika dovodi do zabrane ovrhe i osiguranja protiv stečajnog dužnika i dr. ${ }^{10}$ Pravne posljedice otvaranja stečajnog postupka nastupaju u trenutku kad je rješenje o otvaranju stečajnog postupka objavljeno na mrežnoj stranici e-Oglasna ploča sudova (čl. 158. st. 1. SZ).

\subsection{Obavijest o izlučnom pravu u stečajnom postupku}

Izlučni vjerovnici se rješenjem o otvaranju stečajnog postupka pozivaju da stečajnog upravitelja u roku od 60 dana od dana objave tog rješenja podneskom obavijeste o svojim izlučnim pravima (čl. 129. st. 1. toč. 4. SZ). U toj obavijesti izlučni vjerovnici dužni su obavijestiti stečajnog upravitelja o svom izlučnom pravu, pravnoj osnovi izlučnog prava i naznačiti predmet na koji se njihovo izlučno pravo odnosi, odnosno u obavijesti naznačiti pravo na naknadu za izlučno pravo iz članka 148. SZ (čl. 258. st. 1. SZ).

Obavijesti o izlučnom pravu daju se stečajnom upravitelju na Obrascu 18 Prijava tražbina u stečajnom postupku, a koji obrazac sadrži i rubriku obavijesti o izlučnom pravu. Prema čl. 13. st. 4. SZ propisano je da ako podnesak nije podnesen na propisanom obrascu, sud će ga odbaciti kao nedopušten. Međutim u sudskoj praksi se odstupilo od strogog formalizma, te je zauzeto stajalište da ako pojedini podnesak i nije napisan na obrascu propisanom Pravilnikom ${ }^{11}$, ali tekst tog podneska u potpunosti odgovara tekstu obrasca iz tog Pravilnika, stečajni

${ }^{10}$ Dika, Mihajlo, Pravne posljedice otvaranja stečajnog postupka, Narodne novine, Zagreb, 2002., str. 9.

11 Vidi, op. cit. u bilj. 9. 
sudac samo zbog toga (što podnesak nije podnesen na propisanom obrascu), unatoč odredbi članka 13. st. 4. SZ, takav podnesak ne može se odbaciti kao nedopušten. Ovo stoga jer smisao Stečajnog zakona nije da se podnesci odbacuju samo zato što nisu napisani na pojedinim obrascima, već da se oni odbacuju ako ne sadrže sve ono što za pojedine situacije zakonodavac propisuje Pravilnikom kojim se nastoji postići jednoobraznost sadržaja pojedinih podnesaka. ${ }^{12}$

Stečajni upravitelj dužan je na propisanom obrascu sastaviti tablicu izlučnih prava o kojima su ga obavijestili izlučni vjerovnici, s podacima za identifikaciju izlučnog vjerovnika, pravnom osnovom izlučnoga prava i predmetom izlučnoga prava (čl. 259. st. 1. toč. 3. SZ). U skladu sa tim stečajni upravitelj je dužan na obrascu 19. Tablica prijavljenih tražbina, razlučnih i izlučnih prava sastaviti tablicu izlučnih prava o kojima su ga obavijestili izlučni vjerovnici, u koju će unijeti redni broj, ime i prezime, odnosno tvrtku ili naziv izlučnog vjerovnika, OIB izlučnog vjerovnika, njegovu adresu i sjedište, te pravnu osnovu izlučnog prava i predmet izlučnog prava (čl. 259. st. 1. toč. 3. SZ).

Tablica izlučnih prava objavit će se na mrežnoj stranici e-Oglasna ploča sudova nakon isteka roka za prijavu tražbina, a najkasnije osam dana prije održavanja ispitnog ročišta (čl. 259. st. 2. SZ). Slijedom navedenog, izlučni vjerovnici ne podnose u tijeku stečajnog postupka prijavu svoje tražbine, već samo obavijest stečajnom upravitelju da mu se preda predmet koji nije dio stečajne mase.

Izlučna prava nisu predmetom ispitivanja i zato se ta prava ni ne prijavljuju u stečajnom postupku, već se samo obavještava stečajnog upravitelja o njihovom postojanju. (čl. 260. st. 4. SZ). Stečajni upravitelj upoznaje vjerovnike o tim pravima o kojima je on obaviješten ili za koja je saznao na drugi način.

Prema čl. 198. st. 1. SZ pravne radnje poduzete prije otvaranja stečajnog postupka kojima se remeti pravo na ujednačeno namirenje stečajnih vjerovnika (oštećenje vjerovnik), odnosno kojima se pojedini stečajni vjerovnici stavljaju u povoljniji položaj (pogodovanje vjerovnika), stečajni upravitelj u ime stečajnog dužnika i stečajni vjerovnici mogu pobijati u skladu s odredbama Stečajnog zakona. Prema tome samo stečajni vjerovnici mogu pobijati pravne radnje stečajnog dužnika, a ne i vjerovnici stečajne mase te izlučni i razlučni vjerovnici. $\mathrm{Na}$ temelju iznesenog može se kratko zaključiti da su aktivno legitimirani za pobijanje pravnih radnji stečajnog dužnika stečajni upravitelj i stečajni vjerovnici, dok su izlučni vjerovnici isključeni jer je čl. 147. st.1. SZ izričito propisano da izlučni vjerovnici nisu stečajni vjerovnici. Iz sudske prakse: „Izlučni vjerovnik u stečajnom postupku ne podnosi prijavu tražbine, njega se stečajni postupak ne tiče, on svoje izlučno pravo ostvaruje izvan stečajnog postupka. Osoba koja na temelju svog stvarnog ili obveznog prava može dokazati da neki predmet ne spada u stečajnu masu, nije stečajni vjerovnik. Njeno će se pravo na izdvajanje predmeta utvrđivati prema pravilima koja važe za ostvarivanje tih prava izvan stečajnog postupka. Izlučni vjerovnici ne podnose prijavu tražbine, njih se stečajni postupak ne tiče, jer oni svoje pravo na izlučenje ostvaruju kao da stečaj nije niti otvoren." Visoki trgovački sud Republike Hrvatske, Pž-4551/99 od 23. studenog 1999., objavljeno u časopisu: Pravo i porezi, 2004., br. 6., str. 31.

12 Visoki trgovački sud Republike Hrvatske, Rješenje broj: Pž-1782/16 od 7. travnja 2016., arhiva VODOVOD I ODVODNJA d.o.o. sa sjedištem u Šibeniku. 


\subsection{Predmet izlučnog prava}

Predmet izlučnog prava može biti predmet koji ne spada u stečajnu masu, a prema profesoru Mihajlu Diki to može biti stvar ili pravo. ${ }^{13}$ Name, izlučnom vjerovniku moguće je vratiti njegov predmet samo u slučaju kada se faktično taj predmet još uvijek nalazi u stečajnoj masi. Prema tome, u slučaju ako se predmet ne nalazi u stečajnoj masi izlučni vjerovnik ima pravo na naknadu za svoje izlučno pravo.

Stečajni zakon u članku 148. st. 1. prvo ističe slučaj kada je predmet čije se izdvajanje moglo tražiti dužnik neovlašteno otuđio i to prije stečajnog postupka. U tom slučaju izlučni vjerovnik može zahtijevati da se na njega prenese pravo na protučinidbu, ako ona još uvijek nije ispunjena. Izlučni vjerovnik zahtjev na protučinidbu može zahtijevati iz stečajne mase samo ako se ta protučinidba može izdvojiti iz stečajne mase. U slučaju da je ta protučinidba izvršena i da se ona ne može više izdvojiti iz stečajne mase, tada izlučni vjerovnik može samo kao stečajni vjerovnik tražiti naknadu štete (čl. 148. st. 2. SZ). To bi se radilo u slučaju da je stečajni dužnik prodao neku stvar koja mu je dana u najam, pa izlučni vjerovnik ima kao prvo pravo na protučinidbu od treće osobe tj. mogao bi tražiti da mu se plati za prodanu stvar ako ta protučinidba još nije ispunjena. Međutim, ako je treća osoba ispunila protučinidbu tada izlučni vjerovnik može tražiti samo ako se ta protučinidba još uvijek može izdvojiti iz stečajne mase. Ako ni jedna od prethodnih varijanti nije više moguća, onda izlučni vjerovnik ima pravo samo kao stečajni vjerovnik postaviti svoj odštetni zahtjev. ${ }^{14}$

Dužnik koji je prije otvaranja stečaja prodao tuđu stvar koja nije spadala u njegovu imovinu potražuje od kupca kupovnu cijenu. Ovu tražbinu po osnovi kupovne cijene dužan je, međutim, cedirati bivšem vlasniku stvari na njegov zahtjev. U ovom slučaju dolazi do promjene predmeta izlučenja - umjesto stvari predmet izlučenja postala je tražbina -premda zapravo i nije u pitanju izlučno pravo jer je ta tražbina dio imovine dužnika. Smatra se da predmet izlučenja može biti i tražbina koju je neovlaštena osoba ustupila stečajnom dužniku. ${ }^{15}$

Prema čl. 148. st. 3. SZ ako je predmet čije se izdvajanje traži otuđio privremeni stečajni upravitelj prije otvaranja stečajnog postupka ili stečajni upravitelj nakon otvaranja stečajnog postupka tada izlučni vjerovnik može po svom izboru zahtijevati da se na njega prenese pravo na protučinidbu ako protučinidba nije ispunjena ili zahtijevati protučinidbu iz stečajne mase ako se protučinidba može izdvojiti iz stečajne mase ili zahtijevati naknadu štete kao vjerovnik stečajne mase.

Pozicija izlučnog vjerovnika bolja je ako je stečajni upravitelj otuđio predmet izlučnog prava, jer izlučni vjerovnik tada, ako zahtijeva naknadu štete ima poziciju vjerovnika stečajne mase. Prema tome, postoji mogućnost da izlučni vjerovnik u trenutku otvaranja stečajnog postupka nije imao imovinsko-pravnu tražbinu prema dužniku, već je imao pravo vlasništva na određenoj stvari i pravo zahtijevati od dužnika predaju te stvari. Ako je stečajni upravitelj otuđio predmet čije se izdvajanje moglo tražiti nakon otvaranja stečajnog postupka te ako izlučni vjerovnik ne može zahtijevati da se na njega prenese pravo na protučinidbu jer je ispunjenja stečajnom dužniku ili se ne može zahtijevati protučinidbu iz stečajne mase jer se ne može izdvojiti, preostaje mu jedino zahtijevati naknadu štete kao vjerovniku stečajne mase.

\footnotetext{
${ }_{13}$ Dika, op. cit. u bilj. br. 3., str. 29.

14 Visoki trgovački sud Republike Hrvatske, Pž-4670/06 od 11. lipnja 2008. objavljeno u knjizi: Čuveljak, Jelena, Komentar stečajnog zakona, Narodne novine, Zagreb, 2018., str. 493.

15 Verona, Antun, Zuglia, Srećko, Stečajni zakon sa komentarom, Jugoslavenska štampa d.d., Zagreb,1930., str.158.
} 
Na temelju iznesenog može se kratko zaključiti da se o pravima izlučnih vjerovnika ne odlučuje u stečajnom postupku, te da je pozicija izlučnog vjerovnika bolja ako je stečajni upravitelj otuđio predmet izlučnog prava, jer tada, ako zahtjeva naknadu štete ima poziciju vjerovnika stečajne mase, te se ta tražbina ne prijavljuje. Ako se osporava visina naknade štete koju bi izlučni vjerovnik imao zbog neovlaštenog otuđenja njegovog predmeta izlučnog prava, bilo da pravo na naknadu ima kao stečajni vjerovnik ili kao vjerovnik stečajne mase, o tome se može odlučivati samo i jedino u parničnom postupku, nikako u izvanparničnom postupku. ${ }^{16}$ Dakle u ovom slučaju, neovisno o tome što je predmet čije se izdvajanje traži otuđeno, izlučni vjerovnik ima pravo izbora između triju gore navedena različita načina, a odluka će ovisiti o svim okolnostima konkretnog slučaja. Pored navedenog, predmet izlučenja mogla bi biti prava koja se mogu posjedovati, koja ne pripadaju dužniku ali on faktično izvršava njihov sadržaj. U faktičkoj vlasti dužnika bi se moglo zateći i neko pravo industrijskog vlasništva (izum, know - how, uzorak, model, robni žig, uslužni žig) pa bi imatelj mogao zahtijevati izlučenje iz stečajne mase. ${ }^{17}$

\subsection{Stečajna masa}

Bez postojanja stečajne mase ne provodi se stečajni postupak. Stečajna masa obuhvaća cjelokupnu imovinu dužnika u vrijeme otvaranja stečajnog postupka, te imovinu koju on stekne tijekom stečajnog postupka. Ona služi namirenju troškova stečajnog postupka, ostalih obveza stečajne mase, te tražbina vjerovnika stečajnog dužnika, odnosno tražbina čije je namirenje osigurano određenim pravima na imovini dužnika (čl. 134. st. 1. i 2. SZ).

Nakon otvaranja stečaja stečajni upravitelj dužan je cjelokupnu imovinu dužnika koja ulazi u stečajnu masu uzeti u posjed i njome upravljati. Također je dužan sastaviti popis pojedinih predmeta stečajne mase, a u tome su mu dužni pomagati dužnik pojedinac i prijašnji zastupnici po zakonu dužnika pravne osobe. Za svaki predmet potrebno je navesti njegovu vrijednost. Ako je to potrebno, procjena pojedinih dijelova imovine može se povjeriti vještacima (čl. 221. SZ).

U stečajnu masu ulaze novčana sredstva, pokretne stvari, nekretnine, tražbine i druga prava dužnika stoga stečajni upravitelj mora dobro poznavati propise o vlasništvu i o obveznim pravima da bi mogao utvrditi sačinjava li neka imovina stečajnu masu ili ne. ${ }^{18}$

Stečajnu masu čine dakle sva subjektivna imovinska prava čiji je nositelj stečajni dužnik jer je imovina skup subjektivnih imovinskih prava koja pripadaju jednoj osobi. ${ }^{19}$ Pojedina subjektivna imovinska prava koja pripadaju stečajnom dužniku i time čine imovinu, dakle stečajnu masu i nije moguće uzeti u posjed. Primjerice ako je stečajni upravitelj zatekao ispred skladišnog prostora stečajnog dužnika automobil, tada u stečajnu masu ne ulazi automobil, već pravo vlasništva na tom automobilu ukoliko je nositelj prava vlasništva stečajni

\footnotetext{
${ }_{16}$ Drukčije razmišljanje vidjeti Šimić, Željko, Unovčenje stečajne mase, Zbornik radova Dani Hrvatskog insolvencijskog i ovršnog prava, Lexpera, Zagreb, 2020., str. 39.-40.

17 Eraković, Andrija, Novo uređenje pravnog položaja vjerovnika stečajnog dužnika u knjizi: Dika, Mihajlo (opća redakcija), Treća novela stečajnog zakona, Narodne novine, Zagreb 2003. str. 107.

18 Čuveljak, Jelena, Komentar stečajnog zakona, Narodne novine, Zagreb, 2018., str. 443.

19 Klarić, Petar, Vedriš, Martin, Građansko pravo, Narodne novine, Zagreb, 2008., str. 95.
} 
dužnik. Prema čl. 5. st. 1. Zakona o vlasništvu i drugim stvarnim pravima (dalje u tekstu: ZV) ${ }^{20}$ objekt prava vlasništva je pojedinačno određena stvar, a to može biti pokretnina ili nekretnina, osim onih koje nisu za to sposobne (čl. 2. st. 1. ZV). Stečajni upravitelj će preuzeti u posjed automobil (predmet prava vlasništva) uspostavljanjem svoje faktične vlasti nad njim i u slučaju kada on ne pripada u stečajnu masu. Isto tako, automobil se mogao zateći u posjedu stečajnog dužnika primjerice po osnovi ugovora o ostavi, pa pravo vlasništva ne bi pripadalo stečajnom dužniku kao ostavoprimatelju već bi to pravo pripadalo ostavodavatelju ili trećoj osobi (ostavodavatelj je mogao dati na čuvanje i tuđu stvar) . ${ }^{21}$

Osim navedenog, stečajni upravitelj je dužan sastaviti sustavan pregled u kojem će navesti i usporediti predmete stečajne mase i dužnikove obveze i njihova procjena. Nadalje dužan je sastaviti popis svih dužnikovih vjerovnika za koje je saznao iz knjiga i poslovne dokumentacije dužnika ili na drugi način (čl. 222. st. 1.-2. SZ). Taj popis predmeta stečajne mase, popis vjerovnika te pregled imovine i obveza moraju se izložiti u sudskoj pisarnici najkasnije osam dana prije izvještajnog ročišta, te se svi vjerovnici stečajnog dužnika imaju pravo uvida u te popise (čl. 224. SZ).

Kako prema čl. 148. st. 1. SZ izlučni vjerovnik treba dokazati da neki predmet ne ulazi u stečajnu masu pa je od posebne važnosti odvojiti ono što spada od onoga što ne spada u stečajnu masu, te je obveza stečajnog upravitelja da sastavi popis predmeta stečajne mase od iznimne važnosti. Taj popis pomaže da se utvrde predmeti koji su zatečeni u faktičnom posjedu stečajnog dužnika tj. koji ne spadaju u stečajnu masu jer druga osoba ima pravo vlasništva na tom premetu ili pravu. ${ }^{22}$

Izlučni vjerovnici bi morali moći prepoznati predmet koji se zatekao u posjedu stečajnog dužnika u trenutku otvaranja stečajnog postupka ili je kasnije tijekom stečajnog postupka stečajni dužnik stekao nad njim faktičnu vlast, a ne spada u stečajnu masu. Drugim riječima, stvar koja je u vlasništvu trećih osoba, a zatekle su se kod dužnika u vrijeme otvaranja stečajnog postupka ne ulaze u stečajnu masu. U tom slučaju vlasnici stvari imaju pravo tražiti od stečajnog upravitelja da te stvari izluči iz stečajne mase i da im se predaju. Dakle, kako se stvari koje nisu u vlasništvu dužnika, a zatekle su se kod njega, moraju vratiti njihovim vlasnicima, obveza stečajnog upravitelja da sačini popis predmeta stečajne mase od iznimne je važnosti. Moguće je da stečajni upravitelj zatečenu imovinu kod dužnika smatra da je u vlasništvu dužnika, ali da neka treća osoba ipak ima osnovani izlučni zahtjev. U tom će slučaju popis predmeta stečajne mase svim osobama omogućiti što sve stečajni upravitelj smatra dijelom stečajne mase pa, treće osobe mogu vidjeti koji od tih predmeta možda i ne pripadaju stečajnoj masi, već su u faktičnom posjedu stečajnog dužnika iako druga osoba ima pravo vlasništva na tom predmetu ili pravu. ${ }^{23}$ Tako, ako je otvoren stečajni postupak nad imovinom jednog bračnog druga, udio tog bračnog druga u imovini bračnih drugova ulazi u stečajnu masu ako se na tom udjelu prema općim pravilima ovršnog prava može protiv dužnika provesti ovrha (čl. 136. SZ). Razvrgnuće suvlasništva i podjela imovine bračnih drugova

\footnotetext{
20 Zakon o vlasništvu i drugim stvarnim pravima, Narodne novine, br. 91/96, 68/98, 137/99,22/00 , 73/00, 114/01, 79/06, 141/06, 146/08, 38/09, 153/09, 143/12, 152/14

21 Eraković, op. cit. u bilj. 6., str. 642.

22 Čuveljak, Jelena, Izlučni vjerovnici, Pravo i porezi, 2004., br. 6., str. 31.

${ }_{23}$ Čuveljak, op. cit. u bilj. 18., str. 444.
} 
provest će se izvan stečajnog postupka, na zahtjev stečajnog upravitelja. ${ }^{24}$ Pored navedenog, pravni položaj stečajnog dužnika pojedinca razlikuje se od pravnog položaja dužnika pravne osobe. Učinci otvaranja stečajnog postupka ne odnose se na cjelokupnu imovinu dužnika pojedinca. Ako se provodi stečajni postupak nad imovinom dužnika pojedinca u stečajnu masu ne ulazi imovina dužnika pojedinca na kojoj se ovrha protiv njega ne bi mogla provesti po općim pravilima o ovrsi. Dužnik pojedinac je u istom položaju kao svaki ovršenik (fizička osoba) u ovršnom postupku. ${ }^{25}$ Ako međutim stečajni upravitelj uzme u posjed određeni predmet koji ne ulazi u stečajnu masu (koji je izuzet od ovrhe) dužniku pojedincu treba priznati izlučno pravo na tom predmetu. ${ }^{26}$

\subsection{Pravni temelj za izlučenje predmeta iz stečajne mase}

\subsubsection{Pravo vlasništva}

Izlučno pravo temelji se najčešće na pravu vlasništva. U čl. 30. ZV propisano je da je vlasništva stvarno pravo na određenoj stvari koje ovlašćuje svog nositelja da s tom stvari i koristima od nje čini što ga je volja, te da svakog drugog od toga isključi, ako to nije protivno tuđim pravima ni zakonskim ograničenjima. U granicama tih ovlasti vlasnik ima pravo posjedovanja, uporabe, korištenja i raspolaganja svojom stvari.

Vlasnik ima pravo zahtijevati od osobe koja posjeduje njegovu stvar da mu ona preda svoj posjed te stvari. To svoje pravo može ostvariti i putem prave vlasničke tužbe i putem tužbe predmnijevanog vlasnika. U oba slučaja izlučni vjerovnik je tužitelj, dok je tuženik stečajni dužnik koji posjeduje stvar ili pravo.

Kada je u pitanju prava vlasnička tužba (reivindikacija) aktivno je legitimiran samo vlasnik stvari čiju predaju zahtjeva. On mora dokazati svoje pravo vlasništva, identitet stvari čiju predaju traži i da je stvar u posjedu tuženika. ${ }^{27}$

Izlučni vjerovnik mora stvar koja se nalazi u posjedu stečajnog dužnika opisati po njezinim osobinama koje je razlikuju od istovrsnih stvari, pa ne može zahtijevati stvari kao što su gotov novac pomiješan sa drugim gotovim novcem, vrijednosne papire na donositelja pomiješane s istovrsnima, ako ne postoje okolnosti iz kojih tužitelj može dokazati svoje pravo vlasništva i iz kojih je tuženik morao znati da tu stvar ne smije prisvojiti (čl. 162. st. 2. ZV-a).

Predaja generične ${ }^{28}$ stvari može se zahtijevati samo ako je dovoljno individualizirana. $U$ pogledu neke količine iz nekog roda može se staviti samo obveznopravni zahtjev ali ne i stvarnopravni zahtjev. ${ }^{29}$

Iz sudske prakse: „I z stečajne mase ne može se zahtijevati izlučenje svote novca pa je stečajno vijeće ispravno pošlo od činjenice da je vjerovnik prijavio novčanu tražbinu kao stečajni vjerovnik bez obzira što je u prijavi naveo da svotu novca zahtjeva kao izlučni vjerovnik." Visoki trgovački

\footnotetext{
24 Šimić, op.cit. u bilj. 16., str. 38.

25 Ibidem, str. 37.

${ }^{26}$ Eraković, op. cit. u bilj. 6., str. 643.

27 Gavella, Nikola, Josipović, Tatjana, Gliha, Igor, Belaj, Vlado, Stipković, Zlatan, Stvarno pravo, svezak prvi, Narodne novine, Zagreb, 2007., str. 592.

${ }^{28}$ To su one stvari koje se u prometu određuju po vrsti, rodu, broju, mjeri itd. npr. žito, vino, šećer i sl.

29 Eraković, op. cit. u bilj. 17., str. 109.
} 
sud Republike Hrvatske, Pž-1365/01 od 20. ožujka 2001., objavljeno u knjizi: Dika, Mihajlo (opća redakcija), Treća novela stečajnog zakona, Narodne novine, Zagreb, 2003. str. 115.

Onaj tko još nije stekao pravo vlasništva na stvari ne može tražiti njezino izlučenje iz stečajne mase po toj osnovi bez obzira na to je li ona individualizirana ili nije. Tako, primjerice, ako je prije otvaranja stečaja sklopljen ugovor o prodaji temeljem kojeg se stečajni dužnik kao prodavatelj obvezao predati kupcu automobil, kupac nema pravo zahtijevati da se iz stečajne mase izdvoji i da mu se preda u posjed automobil bez obzira što je platio kupovnu cijenu. $U$ tom slučaju, kupac ima položaj stečajnog vjerovnika i može svoju nenovčanu tražbinu ostvarivati podnošenjem prijave stečajnom upravitelju. Međutim, ako je predaja kupcu izvršena na način propisan u čl. 116. st. 2. ZV-a, automobil je predan kupcu u samostalan posjed tako da je ostao u neposrednom pojedu stečajnog dužnika, kupac je stekao pravo vlasništva i ima pravo tražiti da se automobil izdvoji (izluči) iz stečajne mase. ${ }^{30}$ Time izvršen prijenos vlasništva neće djelovati na prava koja bi treći stjecali na toj stvari ako oni u trenutku svojeg stjecanja nisu znali niti su morali znati da je vlasništvo preneseno drugome (čl. 116. st. 2. ZV.). Pored navedenog, izlučni vjerovnik može ustati i publicijanskom tužbom protiv stečajnog dužnika sa zahtjevom da se iz stečajne mase izdvoji i da mu se preda u posjed određene stvari. U parnici mora dokazati pravni temelj $\mathrm{i}$ istinit način svog stjecanja stvari i da stečajni dužnik stvari posjeduje bez pravnog temelja ili na slabijem pravnom temelju (čl. 166. st. 1. ZV-a). U tom slučaju tužitelj ne mora dokazivati postojanje svog prava vlasništva jer se radi o tužbi predmnijevanog vlasnika, već mora dokazivati činjenice na temelju kojih se predmnijeva njegovo pravo vlasništva i mora dokazati da stvar čije izlučenje traži ne spada u stečajnu masu (147. st. 2. SZ). ${ }^{31}$

Bez obzira na to da li je riječ o vlasničkoj tužbi ili tužbi predmnijevanog vlasnika, teret dokaza je na stečajnom dužniku ako je pravo izlučnog vjerovnoka upisano u zemljišnoj ili kojoj drugoj javnoj knjizi da dokaže da predmet na koji se odnosi to pravo spada u stečajnu masu (čl. 147. st. 2. SZ).

Iz sudske prakse: „Dakle, u konkretnom predmetu, stečajni dužnik je upisan u zemljišne knjige kao vlasnik spornih nekretnina, pa nije ni dužan postupati po odredbi čl. 79. st. 2. Stečajnog zakona, te dokazivati da nekretnine koje su predmetom prodaje spadaju u stečajnu masu stečajnog dužnika. Nasuprot tome, izlučni vjerovnici nisu dokazali da su nekretnine koje su predmetom prodaje, njihovo vlasništvo, jer iz dokumentacije koja prileži spisu je vidljivo da su izlučni vjerovnici tek podnijeli zahtjev za povrat imovine temeljem Zakona o naknadi za imovinu oduzetu za vrijeme jugoslavenske komunističke vladavine, ali o tome još traje postupak, jer nije pravomoćno riješen. Kako izlučni vjerovnici nisu stečajni vjerovnici, to niti sud u stečajnom postupku nije nadležan odlučivati o njihovim zahtjevima, već svoja prava i interese, ako su povrijeđena $i$ ugrožena, mogu ostvarivati izvan stečajnog postupka, na način kako je to određeno odredbama Zakona o naknadi za imovinu oduzetu za vrijeme jugoslavenske komunističke vladavine."Visoki trgovački sud Republike Hrvatske, Pž-6218/03 od 28. listopada 2003., objavljeno u knjizi: Čuveljak, Jelena, Komentar stečajnog zakona, Narodne novine, Zagreb, 2018., str. 488.

Suvlasnici također imaju izlučno pravo kao i osobe koje imaju zajedničko vlasništvo na određenoj stvari. Aktivno su legitimirani svi suvlasnici zajedno, odnosno svi zajednički vlasnici zajedno. Međutim, ako je stečajni dužnik jedan od suvlasnika odnosno zajednički vlasnik, tada ne dolazi do izlučenja stvari iz stečajne mase, već se provodi postupak razvrgnuća

\footnotetext{
30 Ibidem, str. 110.

31 Eraković, op. cit. u bilj. 6., str. 644.
} 
suvlasništva (čl. 47.-56. ZV) odnosno dioba zajedničkog vlasništva (čl. 63. ZV) određivanjem suvlasničkih dijelova i nakon tog razvrgnuća. Svaki suvlasnik koji je sudjelovao u razvrgnuću stječe na temelju sporazuma o razvrgnuću ili pravomoćne odluke suda o razvrgnuću, a na zakonom određeni način pravo vlasništva i/ili neko drugo pravo, izvodeći ga iz onog svoga suvlasničkoga dijela s kojim je sudjelovao u tom razvrgnuću, a koji mu istodobno prestaje (čl. 55. st. 1. ZV). Onaj tko je na ovaj način postao samovlasnik ima naravno izlučno pravo na stvari koja mu pripada. ${ }^{32}$

\subsubsection{Obveznopravni zahtjev}

Navest ću samo neke obvezne odnose koji mogu biti pravna osnova za izdvajanje stvari iz stečajne mase. Naime, u svakom obveznopravnom odnosu koji može biti pravna osnova za izdvajanje stvari iz stečajne mase bitno je utvrditi spada li određeni predmet u imovinu stečajnog dužnika. Kao što sam već naveo, izlučno pravo odnosi se na predmete koji nisu dio imovine stečajnog dužnika, a kome ono pripada i pod kojim pretpostavkama ga može ostvariti, utvrđuje se prema pravilima koja vrijede za ostvarivanje tih prava izvan stečajnog postupka.

\subsubsection{Ugovor o kupoprodaji}

Ugovor o kupoprodaji je životno gledajući svakako najčešći ugovor koji se svakodnevno koristi u pravnom prometu. Prema čl. 376. st. 1.-2. Zakona o obveznim odnosima (dalje u tekstu: ZOO) $)^{33}$ ugovorom o kupoprodaji prodavatelj se obvezuje predati stvar u vlasništvo, a kupac se obvezuje platiti mu cijenu, dok se prodavatelj nekog prava obvezuje pribaviti to pravo kupcu, a kod ostvarivanja njegova sadržaja zahtijeva posjed stvari, predati mu i stvar. U tom smislu, bitni sastojci ugovora o kupoprodaji su stvar koju se prodavatelj obvezuje predati kupcu u vlasništvo i cijena koju se kupac obvezuje platiti. Kupoprodajom se ne stječe vlasništvo, te je kupoprodaja kao valjani pravni posao samo pravna osnova (titulus). Vlasništvo pokretne stvari stječe se predajom te stvari stjecatelju u samostalan posjed na temelju valjano očitovane volje dotadašnjeg vlasnika usmjerene na to da njegovo vlasništvo prijeđe na stjecatelja (čl. 116. st. 1 ZV-a), a vlasništvo nekretnine stječe se (modus) upisom u zemljišnu knjigu (čl. 119 ZV-a). Prema tome, ugovor o kupoprodaji nije pravni temelj za izlučni zahtjev, jer se sklapanjem tog ugovora stječe obveznopravni zahtjev, a vlasništvo se stječe predajom, odnosno upisom stjecateljeva prava u zemljišnu knjigu, a za slučaj da nekretnina nije upisana polaganjem odgovarajuće tabularne isprave u sud (čl. 119-121 ZV). ${ }^{34}$

U čl. 147. st. 3. SZ predviđeno je pravo na vraćanje stvari u slučaju kad je zaključen ugovor o kupoprodaji stvari. Tako prodavatelj kojem cijena nije isplaćena u cijelosti može tražiti da mu se vrati roba koja je iz drugog mjesta poslana dužniku prije dana otvaranja stečajnoga postupka, a do dana otvaranja toga postupka nije prispjela na odredišno mjesto, odnosno ako je do tog dana dužnik nije preuzeo. To znači da isto pravo ima i komisionar za kupnju robe.

\footnotetext{
${ }^{32}$ Ibidem, str. 645.

${ }^{33}$ Zakon o obveznim odnosima, Narodne novine br. 35/05, 41/08, 125/11, 78/15, 29/18.

${ }^{34}$ Eraković, op. cit. u bilj. 6., str. 646.
} 
Pravo na vraćanje trebalo bi priznati prodavatelju i onda kada se smatra da je stvar predana kupcu, kao što je to u slučaju kada je prema ugovoru potrebno izvršiti prijevoz stvari, a ugovorom nije određeno mjesto ispunjenja. Tada je predaja izvršena uručenjem stvari prijevozniku ili osobi koja organizira otpremu. Stečajni dužnik stječe pravo vlasništva već u trenutku uručenja stvari prijevozniku (tada je izvršena predaja), pa je time kupljena stvar postala dio imovine (stečajne mase) i prodavatelj ne bi imao izlučno pravo kad ne bi bilo prava na potragu. ${ }^{35}$

Ako je dužnik preuzeo samo na čuvanje robu koja je stigla na odredišno mjesto prije dana otvaranja stečajnog postupka, prodavatelj nema pravo na vraćanje, ali ima pravo redovnim putem ostvariti svoja prava u svezi s tom robom kao izlučni vjerovnik (čl. 147. st. 5. SZ).

Ako je kupac platio cijenu unaprijed, a nakon toga je nad prodavateljem otvoren stečajni postupak, nema pravo tražiti da se stvar koja je predmet prodaje izluči iz stečajne mase. U tom slučaju kupac prema stečajnom dužniku nema zahtjev za izlučenje jer mu stvar nije predana u posjed, odnosno nije upisao svoje pravo vlasništva u zemljišnoj knjizi na svoje ime kad je u pitanju nekretnina. Kupac, međutim, ima nenovčanu tražbinu koju može ostvariti kao stečajni vjerovnik podnošenjem prijave stečajnom upravitelju. ${ }^{36}$

\subsubsection{Ugovor o komisiji}

Pojam i bitni sastojci ugovora o komisiji uređeni su čl. 785. st. 1. ZOO-a, a koji propisuje da se ugovorom o komisiji obvezuje komisionar obaviti uz proviziju jedan ili više poslova u svoje ime i za račun komitenta. Naime, komisionar sklapa pravne poslove u svoje ime, ali za račun komitenta i u skladu s komitentovim nalogom, pa je on u ugovoru o kupoprodaji kojeg sklapa za račun komitenta prodavatelj odnosno kupac. Stoga kao što sam već rekao pravo na vraćanje ima i komisionar za kupnju robe. U slučaju stečaja komisionara komitent može zahtijevati izlučenje iz stečajne mase stvari što ih je predao komisionaru radi prodaje za njegova račun, a i stvari što ih je komisionar nabavio za njegov račun. $U$ istom slučaju komitent može zahtijevati od trećega kome je komisionar prodao stvar da mu isplati njihovu cijenu, odnosno njezin još neisplaćeni dio (čl. 803. st. 1.-2. ZOO-a). To pravo izlučenja iz stečajne mase stvari koje je dao komisionaru naglašava činjenicu da stvari ostaju u komitentovu vlasništvu, pa ih on ima pravo tražiti u slučaju kada je nad komisionarom otvoren stečajni postupak.

Iz sudske prakse: 1. Komitent je u slučaju stečaja komisionara aktivno legitimiran zahtijevati od treće osobe kojoj je komisionar predao stvari da mu isplati njihovu cijenu. Vrhovni sud republike Hrvatske, Rev - x -5/12 od 28. kolovoza 2012., objavljeno u knjizi: Crnić, Ivica, Zakon o obveznim odnosima s izmjenama iz 2018. i dodatnom sudskom praksom, Organizator, Zagreb, 2018., str. 1242. 2. U slučaju stečaja komisionara komitent može zahtijevati od trećega kome je komisionar predao stvar da mu isplati njezinu cijenu odnosno njezin još neisplaćeni dio. To znači da u takvoj pravnoj situaciji tužitelj kao komitent za naplatu neisplaćenog dugovanja ne mora tražiti odobrenje od komisionara. To što bi se tužitelj, a eventualnio i tuženici, danim im kreditima koristili suprotno njihovoj namjeni, ugovore o kreditu ne čini ništavim. Vrhovni sud Republike Hrvatske, Rev-380/01 od 16. prosinca 2003., objavljeno u knjizi: Crnić, Ivica, Zakon o obveznim odnosima s izmjenama iz 2018. i dodatnom sudskom praksom, Organizator, Zagreb, 2018., str. 1242.

35 Eraković, op. cit. u bilj. 17., str. 111.

${ }^{36}$ Eraković, op. cit. u bilj. 6., str. 646. 


\subsubsection{Pridržaj prava vlasništva}

Kupoprodaja s pridržajem prava vlasništva je je poseban oblik kupoprodaje i jedan od načina zaštite prodavatelja. Pridržaj prava vlasništva moguć je i za pokretnine i nekretnine. Naime, kupoprodaja s pridržajem prava vlasništva postoji kad prodavatelj posebnom odredbom ugovora pridrži pravo vlasništva i poslije predaje stvari kupcu dok kupac ne isplati cijenu u potpunosti (čl. 462. st. 1. ZOO-a). Prema tome, sve do potpune isplate kupoprodajne cijene, prodavatelj može od kupca tražiti da mu prodanu stvar vrati, jer je prodavatelj taj koji je i nadalje ostao vlasnikom stvari.

Radi zaštite kupčevih vjerovnika pridržaj prava vlasništva pokretne stvari ima učinak samo ako je učinjen u obliku javno ovjerovljene isprave prije kupčeva stečaja ili prije pljenidbe stvari (čl. 462. st. 1. ZOO-a). To znači da u slučaju zaključenja ugovora o kupoprodaji nekretnine s pridržajem prava vlasništva nije potrebna javna ovjera takova ugovora jer se kupcu ne dozvoljava uknjižba prava vlasništva do isplate pune kupoprodajne cijene. Prema tome, u slučaju kad je izvršena prodaja stvari uz pridržaj prava vlasništva prodavatelja, onda ako je otvoren stečajni postupak nad kupcem, prodavatelj koji je zadržao vlasništvo stvari može tražiti tu stvar nazad odnosno tražiti da mu se prodana stvar vrati, tj. isti ima izlučno pravo ali samo pod uvjetom da je ugovor o kupoprodaji uz pravo pridržaja ugovoren prije otvaranja stečajnog postupka i u obliku javno ovjerene isprave. Ako pak prodavatelj ne bi zadržao pravo vlasništva, onda on nema pravo tražiti da mu se prodana stvar vrati nazad već može tražiti da mu se isplati ostatak kupoprodajne cijene.

Na pokretnim stvarima o kojima se vode posebne javne knjige može se pridržati pravo vlasništva samo ako je to predviđeno propisima o uređenju i vođenju tih knjiga (čl. 462. st. 4. ZOO-a). No, iz tako određene zakonske odredbe nejasno je o kojim je to pokretninama riječ.

Stečajni dužnik nije postao vlasnik stvari i ona stoga ne ulazi u stečajnu masu ako je prije otvaranja stečajnog postupka dužnik pokretnu stvar kupio uz pridržaj prava vlasništva i stvar dobio u posjed, te u tom slučaju stečajni upravitelj ima pravo izbora u skladu s odredbama čl. 181. SZ (čl. 185. st. 2. SZ). Stečajni upravitelj ima izbor da umjesto dužnika ispuni ugovor i tražiti ispunjenje od druge strane. Druga ugovorna strana nema pravo izbora, ali ima pravo pozvati stečajnog upravitelja da se očituje o svom pravu na izbor. U tom slučaju stečajni upravitelj je dužan odmah, a najkasnije nakon izvještajnog ročišta preporučenom pošiljkom obavijestiti drugu stranu o tome namjerava li zahtijevati ispunjenje ugovora. Iznimno ako bi za drugu stranu do izvještajnog ročišta nastupila znatna šteta, na koju je upozorila stečajnog upravitelja, stečajni upravitelj dužan je u roku od osam dana preporučenom pošiljkom obavijestiti o tome namjerava li zahtijevati ispunjenje ugovora. Ako propusti tako postupiti, stečajni upravitelj neće biti ovlašten zahtijevati ispunjenje ugovora. Prodavatelj koji je zadržao pravo vlasništva ima izlučno pravo ako stečajni upravitelj ne preuzme ugovor. Izlučno pravo mu ne pripada bez obzira na pravo vlasništva ako je stečajni upravitelj preuzeo ugovor. Tada prodavatelj potražuje kupovinu kao vjerovnik stečajne mase, a ne kao stečajni vjerovnik jer je stečajni upravitelj svojom radnjom preuzeo isplatu ostatka kupovine. ${ }^{37}$

Ako je dužnik prije otvaranja stečajnog postupka pokretnu stvar prodao uz pridržaj prava vlasništva i kupcu stvar predao u posjed, kupac može zahtijevati ispunjenje ugovora o kupoprodaji. Isto vrijedi i ako je dužnik preuzeo daljnje obveze prema kupcu te ih u cijelosti ili djelomično nije ispunio (čl. 185. st. 1. SZ).

37 Ibidem, str. 646. 


\subsubsection{Najamni i zakupni odnosi}

Odredbe o Ugovoru o zakupu nalaze se u čl. 519.-549. ZOO-a koje ističu da se tim ugovorom obvezuje zakupodavac predati zakupniku određenu stvar na korištenje, a ovaj se obvezuje plaćati mu za to određenu zakupninu. ZOO također sadrži i odredbe o ugovoru o najmu i to u čl. 550. - 578., u kojima je propisano da se tim ugovorom obvezuje najmodavac predati određenu stvar najmoprimcu na uporabu, a ovaj mu se obvezuje za to plaćati određenu najamninu. Također zakupni i najamni odnosi su uređeni i posebnim propisima i to zakupni Zakonom o zakupu i kupoprodaji poslovnog prostora ${ }^{38}$, a najamni Zakonom o najmu stanova. ${ }^{39} \mathrm{U}$ praksi se pokazalo da se u trenutku otvaranja stečajnog postupka često zatiču sklopljeni ugovori o zakupu i najmu. Stvar koju stečajni dužnik ima u posjedu po osnovi najma ili zakupa ne ulazi u stečajnu masu. Najmodavac odnosno zakupodavac ima izlučno pravo, ali osnovno je pravilo da najam i zakup nekretnine ili prostorija ne prestaju otvaranjem stečajnog postupka. To vrijedi i za najamne i zakupne odnose koje je dužnik sklopio kao najmodavac ili zakupodavac, a tiču se predmeta koji su radi osiguranja preneseni na treću osobu koja je financirala njihovu nabavu i proizvodnju (čl. 186. st. 1. SZ). Iz navedene odredbe čl. 186. st. 1. SZ moglo bi se zaključiti da otvaranjem stečajnog postupka prestaje zakup i najam pokretnina i da zakupodavac odnosno najmodavac može odmah tražiti izdvajanje stvari iz stečajne mase i predaju u posjed. Smatra se, međutim da otvaranje stečajnog postupka djeluje na najam i zakup pokretnina u smislu da je u odnosu na njih pridržano stečajnom upravitelju pravo na izbor hoće li ih održati na snazi ili neće. ${ }^{40}$ Pravo na izbor stečajnom upravitelju u smislu čl. 181. st. 1. SZ pripada u slučaju kad ugovorne strane nisu ispunile ugovor. Ako je stečajni dužnik prije otvaranja stečajnog postupka predao pokretnu stvar najmoprimcu ili zakupcu ili obrnuto, ako mu je stvar predao u posjed najmodavaca ili zakupodavac stečajni upravitelj nema pravo izbora. Ipak, ako stečajni upravitelj ima pravo tražiti predaju u posjed pokretne stvar koja je predmet najma ili zakupa koja stečajnom dužniku nije bila predana prije otvaranja stečaja, ne bi imalo smisla ne priznati mu pravo zadržati stvar koja je dužniku već predana u posjed prije otvaranja stečajnog postupka. ${ }^{41}$ Zakonodavac je čl. 186. st. 2. SZ jasno odredio da sva prava koja se odnose na vrijeme prije otvaranja stečajnog postupka, kao i štetu nastalu prijevremenim otkazom ugovora, druga strana može ostvarivati samo kao stečajni vjerovnik. To znači da se te tražbine moraju prijaviti u stečajnom postupku u rokovima za prijavu tražbina. Iz navedene odredbe proizlazi da prava koja nastanu nakon otvaranja stečajnog postupka, druga strana ostvaruje kao vjerovnik stečajne mase.

\subsubsection{Ugovor o djelu}

Odredbe ugovora o djelu uređene su u čl. 590.-619. ZOO-a, a koje propisuju da se ugovorom o djelu izvođač obvezuje obaviti određeni posao, kao što je izrada ili popravak neke stvari, izvršenje kakva fizičkog ili umnog rada i sl., a naručitelj se obvezuje platiti mu za to naknadu.

\footnotetext{
38 Zakonom o zakupu i kupoprodaji poslovnog prostora, Narodne novine, br. 125/11, 64/15.

39 Zakonom o najmu stanova, Narodne novine, br. 91/96, 48/98, 66/98, 22/06.

40 Dika, op. cit. u bilj. br. 10., str. 96.

${ }^{41}$ Eraković, op. cit. u bilj. 6., str. 648.
} 
Pretpostavimo li da se u trenutku otvaranja stečajnog postupka automobil zatekne u posjedu stečajnog dužnika jer se ugovorom o djelu obvezao izvršiti popravak na automobilu, tada automobil ne bi ušao u stečajnu masu i naručitelj bi ima pravo zahtijevati izdvajanje automobila iz stečajne mase. Prema tome, naručitelj bi također temelj ugovora o djelu u tom slučaju imao izlučno pravo. Međutim, ako se izvođač obvezao izraditi određenu stvar iz svog materijala, naručitelj nema izlučno pravo ni u slučaju kada je stvar u cijelosti izrađena prije otvaranja stečajnog postupka. Drugim riječima, u tom slučaju naručitelj ima nenovčanu tražbinu koju može ostvariti samo u novčanom ekvivalentu kao stečajni vjerovnik prijavom stečajnom upravitelju. ${ }^{42}$

\subsubsection{Ugovor o uskladištenju}

Odredbe ugovora o uskladištenju uređene su u čl. 744.-762. ZOO-a, a koje propisuju da se ugovorom o uskladištenju obvezuje skladištar da primi i čuva određenu robu i da poduzima potrebne ili ugovorne mjere radi njezina očuvanja u određenom stanju te da je preda na zahtjev ostavodavca ili druge osobe, a ostavodavac se obvezuje da mu za to plati određenu naknadu, te je ostavodavac pri predaji robe dužan dati sve potrebne obavijesti o njoj i izjaviti kolika je njezina vrijednost.

U slučaju otvaranja stečaja nad skladištarom svi ostavodavci imaju pravo na povrat njihovih stvari koje su bile zaprimljene u skladištu. Skladištar ne može pomiješati primljene zamjenjive stvari sa stvarima iste vrste i iste kakvoće, osim ako je ostavodavac na to pristao, ili ako je očito da je riječ o stvarima koje se mogu miješati bez opasnosti nastanka štete za ostavodavca (čl. 788. ZOO). U pogledu kada su generične stvari pomiješane, upitno je i dvojbeno postoji li izlučno pravo. Primjerice, ako ima deset ostavodavaca i svaki od njih je dao na uskladištenje deset tona pšenice koja je pomiješana, a nad skladištarom je otvoren stečajni postupak, ta pšenica ne ulazi u stečajnu masu i ostavodavcima bi u tom slučaju trebalo priznati izlučno pravo. U tom pogledu ne bi bilo poteškoća kada bi se sva količina od sto tona pšenice nalazila u skladištu, te bi se tada svakom vjerovniku predalo onoliko koliko je dao na uskladištenje. Međutim treba upozoriti da ako u skladištu ima samo deset tona pšenice ne bi bilo opravdano da se namiri samo onaj vjerovnik koji je prvi zatražio da mu dužnik preda pšenicu. Zbog izostanka posebnih pravila ostaje nepoznato da li u tom slučaju treba ostavodavcu koji je prvi od dužnika zatražio da mu preda pšenicu priznati izlučno pravo. Prema stajalištu suca Vrhovnog suda Republike Hrvatske mr.sc. Andriji Erakoviću čini se da u tom slučaju nije moguće priznati izlučno pravo to stoga što vjerovnik ne može individualizirati stvar čije izdvajanje traži. ${ }^{43}$ Isto tako stvari koje stečajni dužnik ima na temelju ugovora o leasingu i ugovora o ostavi moraju se vratiti u stečajnom postupku njihovim vlasnicima.

Slijedom svega navedenog, izlučni vjerovnici imaju pravo na povrat svih stvari koje se na temelju određenih ugovora nalaze kod dužnika, a ti ugovori nisu osnova za stjecanje prava vlasništva, niti su predmeti koji se traže dio imovine stečajnog dužnika.

Iz sudske prakse: Sudovi su pravilno ocijenili da skladišni list na temelju kojeg tužitelj temelji svoje pravo vlasništva, a koje je izdao tuženik I. nije skladišnica - vrijednosni papir, jer nema bitne

42 Eraković, op. cit. u bilj. 17., str. 113.

43 Eraković, op. cit. u bilj. 6., str. 648. 
elemente iz čl. 741. Zakona o obveznim odnosima (NN br. 53/91 i dr.) pa tužitelj nije mogao steći stvarnopravni zahtjev, jer skladišni list ne može poslužiti kao sredstvo individualiziranja, pretvaranja određene robe u species. Naime, tuženica je time što je izdala skladišni list od 26. ožujka 1998. preuzela obvezu prema trećim osobama da im preda količinu šećera koju označi l.d.d. budući je tuženica s tvrtkom I.d.d. sklopila samo ugovor o pozajmici šećera(istog dana 26. ožujka 1998.) koji nije realizirala, jer iz ugivora o pozajmici l. potvrđuje da nije primila u posjed pozajmljeni šećer niti zatražila otpremu. Stoga, kako tužitelj nije dokazao vlasništvo nad šećerom s obzirom da je otuđen prije otvaranja stečaja, tužitelj je mogao samo u smislu čl. 80. st. 2 Stečajnog zakona tražiti naknadu štete, ali kao stečajni vjerovnik dakle prijaviti tražbinu u novčanom iznosu u stečajnom postupku budući da mu parnica u smislu čl 96. Stečajnog zakona kao redovni put zaštite nije dopuštena. Vrhovni sud Republike Hrvatske, Revt-54/04 od 20. srpnja 2005. objavljeno u knjizi: Čuveljak, Jelena, Komentar stečajnog zakona, Narodne novine, Zagreb, 2018., str. 490.

\section{Izlučna prava u slučaju prodaje imovine dužnika kao cjeline}

Budući da je često imovina poslovnog subjekta kao cjelina veće vrijednosti nego pojedini dijelovi njegove imovine, to stečajni zakon u čl. 235.-246. SZ propisuje pravila koja omogućavaju upravo prodaju dužnika kao cjeline, a što svakako omogućava povoljnije namirenje stečajnih vjerovnika.

Ugovorom o prodaji imovine dužnika kao cjeline mogu biti obuhvaćeni predmet izlučnog prava koji ne pripadaju stečajnoj masi, ali se nalaze u stečajnoj masi. U tom smislu treba razlikovati između faktične stečajne mase koja jest, u kojoj se nalazi sve ono što je u posjedu stečajnog dužnika (tzv. „Ist-Masse“) i one stečajne mase koja sadrži samo ono što doista pripada stečajnom dužniku, dakle, samo ono što treba biti u stečajnoj masi (tzv. „Soll-Masse“). Budući da se imovina stečajnog dužnika prodaje kao cjelina, postoje opasnosti da se na kupca prenesu i stvari koje ne pripadaju stečajnoj masi. Bitno je utvrditi je li izlučno pravo ostvareno, je li pokrenut postupak za njegovo ostvarivanje ili su ispunjene pretpostavke da kupac o pitanju toga ne bude u dobroj vjeri najkasnije u vrijeme prijenosa posjeda stvari, odnosno od trenutka u kojem stječe kakvo pravo čiji je predmet ugovora o prodaji imovine stečajnog dužnika kao cjeline. Stoga čl. 239. SZ propisuje pravila koja uređuju položaj kupca u vezi stvari i prava u pogledu kojih netko ima izlučno pravo i to samo onih koja nisu upisana u javne knjige, a u vrijeme prodaje nalaze se u posjedu dužnika. Zakon polazi od toga da u tim slučajevima u pravilu treba zaštiti kupca.

Stjecanje prava vlasništva od nevlasnika moguće je pod određenim pretpostavkama, a između ostalog, traži se da je stjecatelj u dobroj vjeri (čl. 118. ZV). Kupac ne može biti u dobroj vjeri ako je stvar upisana u zemljišnoj ili kojoj drugoj javnoj knjizi na ime treće osobe. Jedino ako stečajni dužnik ima valjanu pravnu osnovu stjecanja prava vlasništva, npr. ugovor o kupnji nekretnine i uz to da je u neposrednom posjedu nekretnine, kupac imovine kao cjeline bio bi u položaju u kojem se nalazio stečajni dužnik, mogao bi temeljem ugovora kojeg je sklopio stečajni dužnik s vlasnikom (prodavateljem) i ugovora o prodaji imovine kao cjeline ishoditi upis prava vlasništva u zemljišnoj knjizi na svoje ime. ${ }^{44}$ Ako se stvar koja nije upisana u javne knjige nalazi u vrijeme prodaje u posjedu dužnika, danom pravomoćnosti rješenja o

44 Ibidem, str. 649. 
potvrđivanju ugovora o prodaji kupac postaje njezinim vlasnikom u skladu s pravilima o stjecanju prava vlasništva stvari kupnjom u ovršnom postupku iako u odnosu na nju treće osobe imaju izlučno pravo (čl. 239. st. 1. SZ).

U pravnom pogledu kupac će pravo vlasništva steći danom pravomoćnosti rješenja o potvrđivanju ugovora o prodaji, a ako bi kupac preuzeo stvar prije pravomoćnosti predmetnog rješenja tada ne bi stekao pravo vlasništva na stvari bez obzira što mu je stvar predana u posjed. ${ }^{45}$ Dakle, temeljem gore navedenog pravila kupac postaje vlasnikom svih nekretnina i pokretnina te prava koja nisu upisana u zemljišnim ili drugim javnim knjigama, neovisno o tome što stečajni dužnik nije imao pravo vlasništva i što je treća osoba imala izlučno pravo na toj stvari. ${ }^{46}$

Danom pravomoćnosti rješenja o potvrđivanju ugovora o prodaji kupac postaje nositelj tražbina i drugih prava stečajnog dužnika koja nisu upisana u javne knjige u skladu s općim pravilima o stjecanju prava od osoba koje nisu njihovi nositelji iako na njima treće osobe imaju izlučna prava (čl. 239. st. 2. SZ).

Kupac će steći neko ograničeno stvarno pravo koje ne pripada dužniku ako su ispunjene pretpostavke o stjecanju prava vlasništva od nevlasnika u čl. 118 ZV, a jednako i vrijednosne papire na donositelja. ${ }^{47} \mathrm{Na}$ kraju u čl. 239. čl. st. 3. SZ je propisano da u gore iznesenim slučajevima izlučni vjerovnik ima prava iz čl. 148. st. 3. SZ. To znači da izlučni vjerovnik može po svom izboru zahtijevati da se na njega prenese pravo na protučinidbu ako ona još uvijek nije ispunjena ili zahtijevati protučinidbu iz stečajne mase ako se ona još uvijek iz te mase može izdvojiti ili tražiti naknadu pretrpljene štete kao vjerovnik stečajne mase. Dakle, tim je pravilom istaknuto da bi izlučni vjerovnici morali obavijestiti stečajnog upravitelja o svojim pravima a ako stečajni upravitelj nije znao niti mogao znati da određena stvar ne ulazi u stečajnu masu, onda je danom pravomoćnosti rješenja o prodaji ta stvar pripala novom vlasniku. ${ }^{48}$

Iz sudske prakse: „Izlučni vjerovnik ne treba prijaviti svoj izlučno pravo, ali treba podnijeti zahtjev stečajnom upravitelju radi predaje stvari, koja ne pripada stečajnoj masi. lako izlučni vjerovnik ne treba prijaviti svoje izlučno pravo on treba podnijeti zahtjev stečajnom upravitelju da mu preda stvar za koju smatra da ne spada u stečajnu masu. Tek kad stečajni upravitelj dobije zahtjev za izlučenje, izlučni vjerovnik može pokrenuti parnicu za izlučenje iz stečajne mase, što je tužitelj propustio učiniti. Tužitelj međutim, nema izlučno pravo stoga što je sud odbio njegov zahtjev za izlučenjem stvari i ta je odluka pravomoćna. Ali čak kad bi tužitelj i imao izlučno pravo, izlučni vjerovnik ne može ostvariti svoje izlučno pravo ako se predmet čije se izlučenje traži ne nalazi u stečajnoj masi. Tada mu pripada naknada za izlučna prava pod uvjetima propisanima $u$ čl. 80. Stečajnog zakona tj. može po svom izboru a) zahtijevati da se na njega prenese pravo na protučinidbu ako ona još nije izvršena, b) zahtijevati protučinidbu iz stečajne mase ako se još može izdvojiti i c) tražiti naknadu pretrpljene štete kao vjerovnik stečajne mase. Njegov izlučni tužbeni zahtjev ne može biti usmjeren prema stjecatelju izz stečajne mase, već isključivo prema stečajnom dužniku. Iz toga slijedi da treći -tuženi/stjecatelj stvari/ nema pasivnu legitimaciju u

\footnotetext{
45 Ibidem, str. 649.

46 Čuveljak, op. cit. u bilj. 22., str. 31.

${ }^{47}$ Eraković, op. cit. u bilj. 6., str. 649.

48 Čuveljak, op. cit. u bilj. 18., str. 764.
} 
ovom sporu, budući da iza tužbenog zahtjeva ne stoji legitimatio ad causam / građansko-pravna legitimacija/. Dakle u odnosu na trećega -stjecatelja iz stečajne mase izlučni vjerovnik - vlasnik stvari može podići vlasničku tužbu vlasnika neposjednika protiv posjednika nevlasnika." Visoki trgovački sud Republike Hrvatske, Pž-630/02 od 28.6.2002., objavljeno u časopisu: Pravo i porezi, 2004., br. 6., str. 31.

\section{Preuzimanje parnica}

Prema čl. 165. st. 1. SZ parnice o imovini koja ulazi u stečajnu masu, uključujući i arbitražne postupke koji su u vrijeme otvaranja stečajnoga postupka bili u tijeku, stečajni upravitelj preuzet će u ime i za račun stečajnoga dužnika. Parnice u svezi s tražbinama koje se prijavljuju u stečajni postupak ne mogu se nastaviti prije nego što su ispitane na ispitnom ročištu. Istim člankom u st. 2. SZ propisano je da parnice koje su u vrijeme otvaranja stečajnoga postupka bile u tijeku protiv stečajnoga dužnika preuzet će u njegovo ime stečajni upravitelj ako se tiču: 1. izlučenja nekoga predmeta iz stečajne mase 2. odvojenoga namirenja 3. obveza stečajne mase. Protivna stranka, koja je uspjela u parnici iz stavaka 1. i 2. ovoga članka, troškove parničnoga postupka nastale do prekida postupka, kao i troškove nastale nakon prekida postupka ako stečajni upravitelj odmah nakon nastavljanja prekinute parnice prizna tužbeni zahtjev ili se odrekne tužbenoga zahtjeva, može ostvarivati samo kao stečajni vjerovnik. U protivnom troškovi parničnoga postupka nastali nakon prekida namirit će se kao dugovi stečajne mase (165. st. 3. SZ). U skladu sa tim pravilima je i odredba čl. 212 Zakona o parničnom postupku (dalje u tekstu: ZPP) ${ }^{49} \mathrm{i}$ to da se parnični postupak prekida kada nastupe pravne posljedice otvaranja stečajnog postupka. Prema tome, nema razlike između posebnih stečajnih pravila i pravila parničnog postupka o prekidu parničnog postupka koji je u tijeku u trenutku otvaranja stečajnog postupka, te su ista pravila međusobno usklađena. Međutim ta neujednačenost i razlika postoje u pogledu pravila o nastavku postupka. ${ }^{50}$ Naime, na temelju ZPP-a određeno je da će se postupak nastaviti kada stečajni upravitelj ili pravni sljednici pravne osobe preuzmu postupak ili ih sud na prijedlog protivne strane ili po službenoj dužnosti pozove da to učine. Međutim, ta odredba nije u skladu sa gore navedenim stečajnim pravilima iz SZ-a o nastavku postupka, te se zbog te neusklađenosti propisa u praksi javljaju određeni problemi i zlouporabe. ${ }^{51}$

Iz navedenih pravila iz SZ-a o nastavku postupka proizlazi da stečajni upravitelj preuzima samo one parnice u kojima je stečajni dužnik bio tužitelj, no u parničnim postupcima u kojima je on bio tuženik dolazi do obveznog preuzimanja samo ako se ti postupci tiču izlučenja nekog predmeta iz stečajne mase, odvojenog namirenja i obveza stečajne mase. Dakle, stečajni upravitelj uopće nema ovlasti preuzeti parnicu koja nije jedna od tih izričito navedenih parnica. ${ }^{52}$

\footnotetext{
49 Zakon o parničnom postupku, Narodne novine, br. 53/91, 91/92, 58/93, 112/99, 88/01, 117/03, 88/05, 02/07, 84/08, 96/08, 123/08, 57/11, 18/11, 25/13, 89/14, 70/19.

50 Čuveljak, op. cit. u bilj. 18., str. 529.

51 Ibidem., str. 529.

52 Ibidem, str. 530.
} 


\section{Ovrha i osiguranje}

Zabrana otuđenja ili opterećenja koja je protiv dužnika određena prema općim pravilima samo radi zaštite interesa određenih osoba u stečajnom je postupku bez učinka, osim onih do kojih je došlo u svezi s postupkom ovrhe ili osiguranja (čl. 160 SZ). Nakon otvaranja stečajnog postupka pojedini stečajni vjerovnici ne mogu protiv dužnika tražiti ovrhu ili osiguranje na dijelovima imovine koja ulazi u stečajnu masu niti na drugoj imovinu dužnika. Postupci ovrhe i osiguranja koji su u tijeku u vrijeme otvaranja stečajnog postupka prekidaju se. Nakon što ti postupci budu nastavljeni, ovršni sud će ih obustaviti (čl.169. st. 1.-3. SZ). No nakon otvaranja stečajnog postupka izlučni vjerovnici mogu radi ostvarenja svojih prava pokrenuti protiv dužnika postupke ovrhe i osiguranja po općim pravilima ovršnog postupka. Pokrenute postupke ovrhe i osiguranja koje su ti vjerovnici pokrenuli prije otvaranja stečajnog postupka, nastavit će i provesti ovršni sud po pravilima ovršnog postupka..$^{53}$ Ovrha radi ostvarenja tražbina prema stečajnoj masi koje nisu zasnovane pravnom radnjom stečajnog upravitelja nije dopuštena šest mjeseci od otvaranja stečajnog postupka, osim u slučajevima navedenim u čl. 170. st. 2. SZ. Nakon otvaranja stečajnog postupka ne mogu se valjano stjecati prava na dijelovima imovine koja ulazi u stečajnu masu i ako se to stjecanje ne temelji na raspolaganju dužnika ili ovrsi ili osiguranju u korist stečajnog vjerovnika, osim kad se stječe prema načelu povjerenja u zemljišne knjige (čl. 171. SZ).

\section{Pravni položaj izlučnih vjerovnika u međunarodnom stečaju}

U pogledu izlučnih prava na određenim stvarima, primjenjuje se pravo države u kojoj se te stvari nalaze u trenutku otvaranja stečajnog postupka. Tako je određeno da će se u pogledu tih prava na predmetima koji se nalaze u državi priznanja strane odluke o otvaranju stečajnog postupka, primjenjivati pravo države priznanja, ali samo ako se ti predmeti u trenutku otvaranja stečajnog postupka nisu nalazili na području države otvaranja tog postupka (čl. 396. st. 1. SZ).

Iznimka od tog pravila postoji u pogledu predmeta koji su uneseni u javne knjige (npr. brodovi, zrakoplovi i dr.) jer je za njih određeno da će se smatrati kako su se ti predmeti nalazili u državi u kojoj se vode javne knjige. No ta iznimka sukladna je pravilima o tim predmetima koji se unose u javne knjige, jer se njihova pripadnost uvijek utvrđuje na temelju prava gdje se vode javne knjige (čl. 396. st. 2. SZ).

Izlučni vjerovnici ovlašteni su voditi u Republici Hrvatskoj parnične postupke i postupke ovrhe, odnosno osiguranja pod pretpostavkama pod kojima bi ih mogli voditi da je u Republici Hrvatskoj otvoren stečajni postupak (čl. 416. st. 3. SZ).

\section{Zaključak}

Završavajući obradu teme „Pravni položaj izlučnih vjerovnika u predstečajnom i stečajnom postupku“ potrebno je u nekoliko zaključnih misli istaknuti neke temeljne odrednice koje se odnose na ovu problematiku. Otvaranje predstečajnog i stečajnog postupka ne

53 Ibidem, str. 547. 
utječe na izlučna prava, pa se izlučne vjerovnika otvaranje predstečaja i stečaja ne tiče, te oni ni ne prijavljuju svoje tražbine u predstečajnom i stečajnom postupku. Naime, oni u predstečajnom postupku obavještavaju nadležnu jedinicu FINE o svojim pravima, pravnoj osnovi izlučnog prava i dijelu imovine dužnika na koji se odnosi njihovo izlučno pravo, kao i o izjavi pristaju li na izdvajanje predmeta na koje se odnosi njegovo izlučno pravo radi provedbe plana restrukturiranja. To znači da kad je FINA obaviještena o postojanju izlučnog prava onda se točno treba navesti na kojem predmetu postoji to pravo.

Bez obzira što rješenje o otvaranju predstečajnog postupka ne sadrži poziv izlučnim vjerovnicima da obavijeste nadležnu jedinicu FINE o postojanju izlučnog prava, čini se prirodnijim da bi bilo mnogo bolje i korisnije za stečajne vjerovnike kad bi rješenje o otvaranju predstečajnog postupka sadržavalo i poziv izlučnim vjerovnicima da u roku za prijavu tražbine trebaju obavijestiti nadležnu jedinicu FINE o postojanju svog izlučnog prava iz razloga što bi stečajni vjerovnici tako mogli biti upoznati o tim pravima, odnosno imati saznanje koji dio imovine koju koristi dužnik nije njegovo vlasništvo, već vlasništvo izlučnih vjerovnika. Nadalje, predstečajni postupak „nažalost“ ne utječe na izlučne vjerovnike. Glede toga, mišljenja sam da bi bilo teško osmisliti plan restrukturiranja u kojem izlučni i razlučni vjerovnici ne bi morali sudjelovati ako bi imovina dužnika sa financijskim teškoćama bila obuhvaćena izlučnim i razlučnim pravima. Stoga, bez daljnjeg korištenja predmeta na kojima postoji izlučno i razlučno pravo dužnik u pravilu neće biti u mogućnosti ostvariti plan restrukturiranja. $U$ tom smislu valja istaknuti i to da u predstečajnom postupku nisu dovoljno razrađene odredbe o mogućnosti uzimanja novih kredita i financiranju plana restrukturiranja.

U stečajnom postupku izlučni vjerovnici obavještavaju stečajnog upravitelja o svom izlučnom pravu, pravnoj osnovi izlučnog prava i predmetu na kojeg se njihovo izlučno pravo odnosi. Izlučno pravo se odnosi na predmete koji nisu dio imovine stečajnog dužnika, stoga se izlučni vjerovnici ne namiruju iz stečajne mase već na temelju svoga stvarnog ili obveznog prava imaju zapravo zahtjev za izlučenje predmeta upravo zbog toga što ta stvar ne spada u stečajnu masu.

Vjerovnik dužnika stječe položaj stečajnog vjerovnika podnošenjem prijave potraživanja stečajnom upravitelju. Od tog trenutka vjerovnik je legitimiran u stečajnom postupku, međutim izlučne vjerovnike se stečajni postupak ne tiče, te mogu zahtijevati da se neki predmet izluči iz stečajne mase po općim pravilima neovisno o stečajnom postupku i to na jednak način kao da stečaja nema.

\section{LITERATURA:}

Knjige:

1. Crnić, Ivica (2018) Zakon o obveznim odnosima s izmjenama iz 2018. i dodatnom sudskom praksom, Organizator, Zagreb.

2. Čuveljak, Jelena (2018) Komentar stečajnog zakona, Narodne novine, Zagreb.

3. Dika, Mihajlo (1988) Insolvencijsko pravo, Pravni fakultet u Zagrebu, Zagreb.

4. Dika, Mihajlo (2002) Pravne posljedice otvaranja stečajnog postupka, Narodne novine, Zagreb. 
5. Dika, Mihajlo, Eraković, Andrija, Garašić, Jasnica, Hrastinski Jurčec, Ljiljana, Lovrić, Viktorija, Marković, Nevenka, Vukelić, Mario (2003) Treća novela stečajnog zakona, Zagreb.

6. Gavella, Nikola, Josipović, Tatjana, Gliha, Igor, Belaj, Vlado, Stipković, Zlatan (2007) Stvarno pravo, svezak prvi, Narodne novine, Zagreb.

7. Gavella, Nikola, Josipović, Tatjana, Gliha, Igor, Belaj, Vlado, Stipković, Zlatan (2007) Stvarno pravo, svezak drugi, Narodne novine, Zagreb.

8. Klarić, Petar, Vedriš, Martin (2008) Građansko pravo, Narodne novine, Zagreb.

9. Verona, Antun, Zuglia, Srećko (1930) Stečajni zakon sa komentarom, Jugoslavenska štampa d.d., Zagreb.

Članci:

1. Čuveljak, Jelena (2004) Izlučni vjerovnici, Pravo i porezi, br. 6.

2. Eraković, Andrija (2003) Izlučna i razlučna prava u stečaju, Zbornik Pravnog fakulteta u Rijeci, br. 1.

3. Eraković, Andrija (2003) Novo uređenje pravnog položaja vjerovnika stečajnog dužnika u knjizi: Dika, Mihajlo (opća redakcija), Treća novela stečajnog zakona, Narodne novine, Zagreb.

4. Garašić, Jasnica (2017) Najznačajnije novine stečajnog zakona iz 2015. godine, Zbornik Pravnog fakulteta u Rijeci, br. 1.

5. Marković, Nevenka (2014) Pravni položaj vjerovnika u postupku predstečajne nagodbe, u knjizi: Barbić, Jakša (ur.), Hrvatsko insolvencijsko pravo, Hrvatska akademija znanosti i umjetnosti, Zagreb.

6. Šimić, Željko (2020) Unovčenje stečajne mase, Zbornik radova Dani Hrvatskog insolvencijskog i ovršnog prava, Lexpera, Zagreb.

\section{Zakoni:}

1. Stečajni zakon, Narodne novine, br. 71/15,104/17;

2. Zakon o vlasništvu i drugim stvarnim pravima, Narodne novine, br. 91/96, 68/98, 137/99, 22/00 73/00, 114/01, 79/06, 141/06, 146/08 38/09, 153/09, 143/12,152/14;

3. Zakon o obveznim odnosima, Narodne novine, br. 35/05, 41/08, 125/11, 78/15, 29/18.

4. Zakonom o zakupu i kupoprodaji poslovnog prostora, Narodne novine, br. 125/11, 64/15.

5. Zakonom o najmu stanova, Narodne novine, br. 91/96, 48/98, 66/98, 22/06.

6. Zakon o parničnom postupku, Narodne novine, br. 53/91, 91/92, 58/93, 112/99, 88/01, $117 / 03,88 / 05,02 / 07,84 / 08,96 / 08,123 / 08,57 / 11,18 / 11,25 / 13,89 / 14,70 / 19$. 
Summary

\section{THE LEGAL POSITION OF CREDITORS WITH THE RIGHT OF SEPARATION IN PRE-BANKRUPTCY AND BANKRUPTCY PROCEEDINGS}

This paper presents an overview of the rights of separation and the legal position of creditors with the right of separation in pre-bankruptcy and bankruptcy proceedings. The paper provides special attention to the examination of the objects of the right of separation and the legal basis for the separation of objects from the bankruptcy estate, and also examines what is important for the exercise of the right of separation, the compensation for the rights of separation and the legal position of creditors with the rights of separation in the event of the disposal of debtor's assets as a whole.

Keywords: right of separation, creditors with the right of separation, object of separation, basis of separation. 